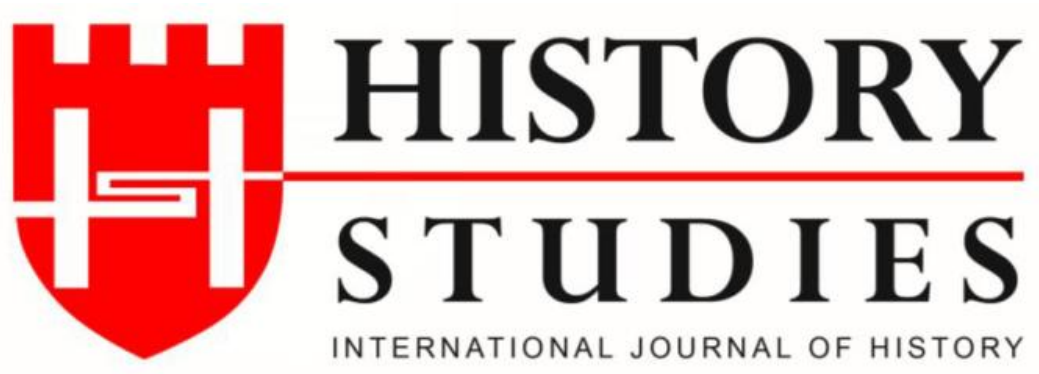

ISSN: 13094173 (Online) 1309 - 4688 (Print)

Volume 12 Issue 4, August 2020

DOI Number: 10.9737/hist.2020.915

Araştırma Makalesi

Makalenin Geliş Tarihi: 01.05.2020 Kabul Tarihi: 29.06.2020

Atıf Künyesi: Ozan Tuna - Nazlı Murzioğlu, “Dönemin Avusturya Die Neue Zeitung Gazetesi’ne Göre Çanakkale Deniz Muharebesi (3 Kasım 1914-18 Mart 1915)", History Studies, 12/4, Ağustos 2020, s. 2161-2176.

\title{
Dönemin Avusturya Die Neue Zeitung Gazetesi'ne Göre Çanakkale Deniz Muharebesi (3 Kasım 1914-18 Mart 1915)
}

\section{Dardanelles Naval Battle According to the Austrian Die Neue Zeitung Newspaper (3 November 1914-18 March 1915)}

\author{
Ozan Tuna - Nazlı Murzioğlu \\ ORCID No: 0000-0003-4762-4286 / 0000-0003-1889-7103 \\ Ondokuz Mayıs Üniversitesi
}

\begin{abstract}
Öz: Çalışmamızda Birinci Dünya Savaşı'nda Osmanlı Devleti'nin müttefiki olan Avusturya-Macaristan'da yayınlanan Die Neue Zeitung gazetesinin Ağustos 1914-Nisan 1915 sayıları incelenmiş olup bu süre zarfında Çanakkale Boğazı özelinde yapılan tahkimatlar, bombardımanlar, sevkiyatlar ve planlamalar kullanılmıştır. Gazete, haberlerini Viyana haricinde müttefiki olması sebebi ile çoğunlukla İstanbul üzerinden aldığı bilgilerle vermiș olup, bazen Atina, Selanik, Roma, Amsterdam, Hamburg gibi şehirlerden aldığ bilgilerle de sağlamıştır. Bu açılardan bakıldığında pek çok şehirden aldığı kaynakları Çanakkale Savaşları özelinde haber yapan gazete araştırmamıza değerli bir kaynak oluşturmuş olup, görsel materyalleri ile de araştırmamızı zenginleştirmiştir. Haberlerinde neredeyse tamamen müttefiki Türkiye yanlısı duruș sergileyen Avusturya gazetesi, Türk askerini ve Türk yönetimini övmüş ve cepheden aldığı Türk ordusunun her başarısını da manşetine taşımıştır. 18 Mart 1915 zaferinden de yazılarında büyük bir övgü ile bahseden gazete, bu başarıyı dünya savaş tarihinde büyük iz bırakan bir zafer olarak nitelendirmiş olup, Suffren isimli Fransız savaș gemisinin Çanakkale Boğazı'nda batırılışının da Almanya'da büyük bir sevinçle karşılandığını haber yapmıştır.
\end{abstract}

Anahtar Kelimeler: Birinci Dünya Savaşı, Çanakkale Deniz Muharebesi, Osmanlı Devleti, Avusturya-Macaristan, Die Neue Zeitung,

Abstract: In this study, the periodicals dated August 1914 and May 1915 of Die Neue Zeitung newspaper which belongs Austria-Hungary, an ally of Ottoman State have been examined in detail. Since Austria-Hungary was an ally of Ottoman State, the newspaper reported about the war in detail between 3 November 1914 and 18 March 1915. Fortifications, bombardments, shipments, and planning for the battle during this period were mentioned in the newspaper. Since Ottoman Empire is an ally of Austria- Hungary, the newspaper usually took the information from İstanbul and sometimes from Athens, Thessaloniki, Rome, Amsterdam and Hamburg; therefore, the newspaper is a valuable source for our study since it provides different point of views. Also, the visual materials obtained from the newspaper have enriched our study. Clearly, Die Neue Zeitung took sides with Turkey in its news by praising the Turkish soldier and Turkish government, and 
it also brought the successes of Turkish side up to the agenda. Besides, the newspaper described the triumph of 18 March as persistent success and also mentioned about the French warship Suffren's submergence in the Dardanelles, which was welcomed with cheers in Germany.

Keywords: First World War, Dardanelles Naval Battle, Ottoman Empire,Austria-Hungary, Die Neue Zeitung.

\section{Giriş}

20. yüzyılda Avrupa'da siyasi durum son derece gerginleşti. Emperyalist yayılma ve sömürgecilik yarışları hız kazandı. Sömürge yarışına geç kalan Almanya İngiltere'nin denizlerdeki gücüne rakip olma arzusundaydı. ${ }^{1}$ Almanya'nın Bağdat demiryolu imtiyazını da elde ederek yönünü doğuya çevirmiş olması İngiltere'nin sömürgelerini tehdit ediyordu. ${ }^{2}$ İngiltere ve Fransa dünyadaki egemen konumlarını sağlama almak, Almanya ve AvusturyaMacaristan İmparatorluğu ise sömürge yarışına yetişmek istedikleri için bu rekabete dâhil olmuşlardı. Yüzyıllar boyunca açık denizlere ve Ortadoğu'ya açılmayı hedefleyen Rusya, Avrupa'da oluşan bu guruplara ilk önce ters düşmüştü. Ancak daha sonra Fransa ile İngiltere çıkması olası Dünya Savaşı'nda insan gücünden faydalanabilmek maksadıyla, Türk Boğazlarından ödün vermek pahasına Rusya'yı yanlarına çekerek, Almanya, AvusturyaMacaristan ve İtalya arasında oluşturulan Üçlü İttifak'a karşı İngiltere tedbir olarak Rusya ve Fransa ile Üçlü İtilafı meydana getirmiştir. ${ }^{3} 1914$ yılında Avrupa adeta patlamaya hazır bir bombayd1.18 Haziran 1914'te Avusturya Macaristan veliahdı Arşidük Franz Ferdinand'ın, Bosna'da bir Sırplı tarafından öldürülmesi bombanın fitilini ateşleyen olay oldu. ${ }^{4} \mathrm{Bu}$ olay üzerine 28 Temmuz'da Almanya'nın savaş durumunda kendini destekleyeceğinden emin olan Avusturya, Belgrad'1 bombaladı. Aynı gün Avusturya-Sırbistan savaşı başlamış oldu. Sırbistan'a yapılan saldırıya kayıtsız kalamayan Rusya ise seferberlik ilan ederek savaş hazırlıklarına başladı. Almanya, Rusya'dan on iki saat içinde tüm savaş hazırlıklarını durdurmasını ve barış zamanı düzenine dönmesini istedi. Ancak Rusya ültimatoma cevap vermeyince, Almanya 1 Ağustos'ta Rusya'ya savaş ilan etti. Bundan sonra savaş ilanları birbirini izleyecekti. Zira bu savaşlara İngiltere ve Fransa kayıtsız kalamazd1. ${ }^{5}$

Almanya'nın Akdeniz filosunu oluşturan Goeben zırhlısı ile Breslau savaş gemilerinin 10 Ağustos 1914'de Çanakkale Boğazı'ndan içeriye girmeleri ile 16 Ağustos 1914'de her iki savaş gemisinin Osmanlı Devleti tarafından satın alınıp, Türk donanmasına katılmaları müttefik donanmasının (İngiltere ve Fransa) Çanakkale Boğazı önünde yoğunlaşmasına sebebiyet vermiştir. ${ }^{6} \mathrm{Bu}$ yoğunlaşma ilk önceleri özellikle Yavuz ve Midilli savaş gemilerinin Çanakkale Boğazı'ndan çıkışlarını önlemek üzerine olmuş olup, bu bağlamda 27 Eylül 1914'de bölgede keşif yapan Akhisar torpidobotu, müttefik donanması muhripleri tarafindan geri dönmeye zorlanmıştır. $\mathrm{Bu}$ olayın üzerine Boğaz, Osmanlı Donanma Komutanlığı tarafindan torpil döşenmek suretiyle trafiğe kapatılarak, yabancı ticaret gemilerinin gidiş ve gelişleri yasaklanmıştır. ${ }^{7}$ Die Neue Zeitung Gazetesi de 28 Eylül 1914 tarihi itibariyle Çanakkale Boğazı'nın kapatıldığını ve bu tarihten itibaren hiçbir geminin Çanakkale Boğazı'ndan giriş ve

\footnotetext{
${ }^{1}$ Burak Gülboy, Birinci Dünya Savaşı Tarihi, Altın Kitaplar Yayınevi, İstanbul 2004, s.34

${ }^{2}$ Bülent Özdemir, Abdülmecit Mutaf, Çanakkale Muhârebatı, Türk Tarih Kurumu Yayınları, Ankara 2012, s.3.

${ }^{3}$ Figen Atabey, Çanakkale Muharebesinde Deniz Cephesi, Türk Tarih Kurumu Yayınları, Ankara 2014, s.1.

${ }^{4}$ Şevket Süreyya Aydemir, Makedonya'dan Orta Asya'ya Enver Paşa, C.II, Remzi Kitabevi, İstanbul 1981, s.507.

${ }^{5}$ Aydemir, age, ss. 508-509.

${ }^{6}$ Sean McMeekin, I. Dünya Savaşı'nda Rusya'nın Rolü, (çev: Nurettin El-Hüseyni), Yapı Kredi Yayınları, İstanbul 2013, ss. 130-131; Atabey, a,g,e, ss. 10-11.

${ }^{7}$ Durdu Mehmet Durak, Birinci Dünya Savaşı ’nda Türk-Ingiliz İlişkileri, Babil Yayıncılık, Ankara 2004, s. 64.
} 
çıkışlarına müsaade edilmeyeceğini, Çanakkale Boğazı’nda ilave önlemler alındığını ve Osmanlı Devleti'nin kara sularını altı mile çıkarttığını duyurmuştur. ${ }^{8}$

27 Ekim 1914'de Yavuz ve Midilli'nin dâhil olduğu filonun Karadeniz'e açılması ve devamında gelişen olaylar Osmanlı Devleti'nin kendisini savaşın içinde bulmasına neden olacaktı. 29 Ekim'de Rus filosu ile temasa geçilmesiyle çatışma çıktı. Rus gemileri batırılarak mürettebatı esir alındı. Ruslara ait olan Sivastapol ve Novorosisk limanları da bombardıman edildi. Osmanlı Devleti, Rus donanmasının Boğaz'dan çıkacak olan Türk gemilerini batırmak amaciyla torpido döktüğünü düşünmüştü. ${ }^{9}$ Bu olay üzerine 2 Kasım 1914'te İngiltere, Fransa, Rusya, Belçika, Japonya, Sırbistan ve Karadağ Türkiye ile diplomatik ilişkilerini kesmiştir. ${ }^{10}$ Önce Rusya 2 Kasım'da Osmanlı Devleti'ne savaş açtı. 5 Kasım'da İngiltere ve Fransa Osmanlı'ya savaş ilan ettiklerini bildirdiler. Osmanlı Devleti ise 11 Kasım 1914'te padişah bildirisiyle müttefiklere savaş ilan ettiğini duyurdu. Bu bildiride Rusların eğitim yapan Osmanlı harp filosuna müdahale etmek suretiyle savaşa sebebiyet verdikleri açıklandı. Harp ilanını takiben, 14 Kasım'da Osmanlı Devleti Cihad-1 Ekber ilan ederek tüm Müslümanları silah altına çağırdı. ${ }^{11}$ Böylelikle Osmanlı Devleti Dünya Savaşı'na sürüklenmiş oldu.

\section{3 Kasım 1914 Bombardımanı}

Avusturya gazetesi, Çanakkale Boğazı tahkimatları ile ilgili kapsamlı bir makale yayınlamıştır. Çanakkale Boğazı tahkimatlarının (Seddülbahir, Ertuğrul, Orhaniye, Kumkale) İstanbul'un denizden savunulmasına uygun olarak oluşturulduğunu ve tahkimatların bu önemlerini hiçbir zaman kaybetmediklerini belirterek, bu tahkimatların Trablusgarp ve Balkan Savaşları'nda uğradıkları saldırıya rağmen kısa süre içerisinde mükemmel bir hale getirildiklerini ifade etmiştir. Bununla birlikte, Çanakkale Boğazı'nın ana savunma hattının birbirlerine 5-6 km mesafede olan Seddülbahir ve Kumkale bataryalarınca oluşturulduğunu ve bu bataryaların güney kanadından Kumkale tahkimatı ile desteklendiği vurgulanmıştır. ${ }^{12}$ Gazete, aynı makalede bu tahkimatların Çanakkale Boğazı önündeki müttefik donanmasını durdurmada yetersiz kalacağını, tahkimatları çok sayıda topçu bataryalarına sahip olmalarına rağmen müttefik savaş gemilerinin bataryaları yandan ateş altına alarak kendilerine güvenli bir koridor açabilecekleri tespitinde bulunmuştur. ${ }^{13}$

Türk donanması, uzun süre hazırlıklarını tamamladıktan sonra 29 Ekim 1914'de Karadeniz'deki Rus donanmasının en önemli limanları olan Odessa, Sivastopol, Novorossik ve Kefe limanlarını bombalamış ve 700 tane mayın yüklü Prut mayın gemisini de batırıp personelini de esir almıştır. ${ }^{14}$ Bunun üzerine 1 Kasım 1914'de Rusya ardından İngiltere ve Fransa, Osmanlı Devleti’ne savaş ilan etmişlerdir. ${ }^{15} 3$ Kasım 1914 tarihinde Çanakkale Boğazı önündeki müttefik donanmasına bağlı savaş gemileri Çanakkale Boğazı'nı bombalamış ve 17

\footnotetext{
8 "Die Dardanellensperre: Vorkehrung der Turkei für Einen Konfliktfall”, Die Neue Zeitung, 3 Ekim 1914, s. 2, "Die Sperrung der Dardanellen", Die Neue Zeitung, , 6 Ekim 1914, s.4.

9 Bilal Gök, "Çanakkale Deniz ve Kara Savaşları: Sebepleri, Gelişimi ve Sonuçları”, Kafkas Üniversitesi Ilahiyat Fakültesi Dergisi, 2, 2014, s.117.

${ }^{10}$ Hülya Toker-Mustafa Toker, Çanakkale Muharebeleri Kronolojisi, Alfa Yayınevi, İstanbul 2015, s.68.

${ }^{11}$ Atabey, age, s.19.

12 "Der Kampf um die Dardanellen", Die Neue Zeitung, 5 Mart 1915, s. 3.

13 "Der Kampf um die Dardanellen", Die Neue Zeitung, 5 Mart 1915, s. 3.

${ }^{14}$ Ozan Tuna, “Amiral Souchon'un Donanma Komutanı Olması ve Rus Limanlarını Bombalaması (29 Ekim 1914)”, Ankara Üniversitesi Osmanlı Tarihi Araştırma ve Uygulama Merkezi Dergisi (OTAM), S. 36, Güz 2014, ss. $215-$ 217.

${ }^{15}$ Toker ve Toker, age, s.68.
} 
dakika süren bombardıman neticesinde Seddülbahir tabyasındaki cephane havaya uçmuş olup, toplamda seksen Türk askeri yaşamını yitirmiştir. ${ }^{16}$

Die Neue Zeitung Gazetesi, 3 Kasım 1914 bombardımanı ile ilgili haberinde İngiliz ve Fransız savaș gemilerinin Canakkale Boğazı dıș tahkimatlarını 10 dakika boyunca bombaladıklarını ve bombardıman esnasında bir Türk torpidobotunun da karşılık verdiğini ifade etmiştir. ${ }^{17} 3$ Kasım 1914 bombardımanı ile ilgili 4 Kasım 1914'de Londra'dan yapılan açıklamayı haber yapan Avusturya gazetesi haberinde, 3 Kasım 1914'de sabah gün ağarırken İngiliz ve Fransız savaş gemilerinin aynı mesafeden Çanakkale Boğazı dış istihkâmlarını bombaladıklarını ifade etmiştir. Gazetenin aynı haberinde Londra'dan bildirildiği üzere Türk tahkimatlarının karşı atışları, müttefik gemilerine yetişmezken sadece bir top mermisinin geminin yakınlarında patladığını belirtilmiştir. Londra'dan alınan bilgiye göre, Türk tahkimatlarından birisinde meydana gelen patlama neticesinde yoğun duman yükseldiği gözlenmiştir. Bununla birlikte, İstanbul'dan aldığı bilgiyi okurları ile paylaşan gazete, 3 Kasım 1914 bombardımanına İngiliz donanmasına ait Irresistible, Indefatigable, Glaucester, Defence ve aynı sınıftan başka bir savaş gemisi ile Fransız donanmasına ait Republique, Bouvet ve iki adet aynı sınıftan savaş gemisi ile sekiz tane Fransız torpidobotunun katıldığını bildirmiştir. Bombardımanda müttefik donanması 240 top atarken Türk tahkimatları 10 tane top ile karşılık vermiştir. Gazetenin İstanbul'dan elde ettiği bilgiye göre, bu bombardıman esnasında bir İngiliz savaş gemisi vurulmuştur. ${ }^{18}$

3 Kasım 1914 bombardımanı Türkiye açısında ciddi bir uyarı maiyeti oluşturmuş olup, bölgenin takviye edilmesi gerekliliği ortaya çıkmışır. ${ }^{19} 3$ Kasım 1914 bombardımanının ardından müttefik donanması, 19 Şubat 1915'e kadar Çanakkale Boğazı'na bombardıman düzenlemezken Avusturya gazetesi, 25 Aralık 1914 tarihli sayısında müttefik donanmasının Çanakkale Boğazı'na denizden yapacağı saldırı için hazırlıklarına devam ettiği bilgisini okurlarına vermiştir. ${ }^{20}$ Gazete, Çanakkale Boğazı harekâtının diplomasi boyutunu da ele almış olup İngiltere ve Rusya'nın Çanakkale Boğazı üzerinde anlaşmaya çalıştıkları hususunda haber yapmıştır. ${ }^{21}$ Gazete, daha sonra 3 Mart 1915 tarihli haberinde bu konuyu daha ayrıntılı bir şekilde ifade etmiş olup, Çanakkale Boğazı ve İstanbul üzerinde İngiltere ve Rusya arasında bir anlaşma yapıldığını belirtmiştir. ${ }^{22}$ Avusturya gazetesi, bu haberi Hamburger Nachrichen Gazetesi'nin Roma'daki bir muhabiri üzerinden elde ettiğini belirtmiştir. Bu haber göre varılan anlaşma, İstanbul'un Rusya'ya bırakılması ve Rusya'nın Çanakkale Boğazı üzerinden Akdeniz'e inmesi karşılığında, Ruslar tarafından Afganistan'daki İngiliz varlığının tanınması şeklinde olmuştur. Bununla birlikte İngiltere'nin Tibet'ten Batı'ya doğru, Rusya'nın güneye inmesini engelleyecek şekilde, Rusya'yı kuşatıcı faaliyetlerden vazgeçmesi üzerinde de anlaşıldığ ifade edilmiştir. ${ }^{23}$

\section{19 Şubat 1915 Bombardımanı}

Müttefik donanması Komutanı Amiral Carden'in gerçekleştirdiği strateji çerçevesinde 19 Şubat 1915 'de Çanakkale Boğazı'na bir öncü saldırı yapılmasına karar verilmiştir. ${ }^{24}$ Die Neue

\footnotetext{
${ }^{16}$ Atabey, age, s. 22.

17 “Bombardement der Dardanellen”, Die Neue Zeitung, 5 Kasim 1914, s. 2.

18 "Beschiessung der Dardanellen Forts", Die Neue Zeitung, 6 Kasim 1914, s.4.

${ }^{19}$ Atabey, age, ss. 22-23

20 "Eine Neue Aktion der Englishe-Französischen Flotte gegen Dardanellen”, Die Neue Zeitung, 25 Aralık 1914, s.4.

21 "Einigung England mit Russland in der Dardanellen Frage", Die Neue Zeitung, 12 Ocak 1915, s. 2.

22 "Ein Englisch-Russisches Geheimabkommen über Dardanellen", Die Neue Zeitung, 3 Mart 1915, s. 4.

23 "Ein Englische-Russiches Geheimabkommen über Dardanellen”, Die Neue Zeitung, 3 Mart 1915, s. 4.

${ }^{24}$ Atabey, age, s. 73.
} 
Zeitung Gazetesi, müttefik donanmasının 19 Mart 1915 saldırı öncesinde Çanakkale Boğazı önündeki yığınak yapması ile ilgili faaliyetleri üzerine kısa bilgiler vermekte idi. ${ }^{25}$

19 Şubat 1915 sabahı başlayan müttefik saldırısının hedefi boğazın dış tabyalarını tahrip etmekti. ${ }^{26}$ Müttefik gemileri önce Anadolu yakasındaki Kumkale ve Orhaniye, daha sonra da Rumeli yakasındaki Ertuğrul ve Seddülbahir tabyalarını bombardıman etti. ${ }^{27}$ Üç saat süren çatışmada Orhaniye ve Ertuğrul tabyaları tarafindan müttefik donanmasına otuz sekiz adet mermi ile karşıllk verilmiştir. ${ }^{28}$ Orhaniye tabyasından atılan mermi Vengeance zırhlısının hasar görmesine sebep oldu ve saat 17.30 'da Amiral Carden görüş koşulları elverişsiz olduğu için filoya geri çekilme emri verdi. ${ }^{29}$ Avusturya gazetesi, 19 Şubat 1915 harekâtında düzenlenen bombardımanı başarısız bulmuş olup harekât esnasında bir İngiliz savaş gemisinin Türk topçuları tarafından vurulduğunu belirtmiştir. ${ }^{30}$

\section{25 Şubat 1915 Bombardımanı}

25 Şubat 1915 sabahı erken saatlerde Limni tarafindan gelen sekiz İngiliz savaş gemisi Bozcaada'nın kuzeyinde mevcut dört adet Fransız savaş gemisi ile birleşerek boğaza doğru ilerlemeye başladı. ${ }^{31} \mathrm{Bu}$ taarruzdaki amaç, 19 Şubat 1915 bombardımanında tahrip edilmeyen boğaz giriş tahkimatlarını da imha etmekti. ${ }^{32}$ Taarruza dönemin en güçlü ve modern gemileri olan Queen Elizabeth ve Irresistible'ın yakın mesafeden tabyaları bombardıman etmeleri ile başland $1{ }^{33}$ Saat 11.00 'de Boğaz girişindeki tüm tabyalar, gemilerin şiddetli ateşleri karşısında susmak zorunda kalmışlar ve 25 Şubat 1915 saldırısı sonucunda boğaz girişindeki tabyalar tamamen hasara uğratılmıştır. ${ }^{34}$ Die Neue Zeitung Gazetesi, 25 Şubat 1915 günü öğleden önce saat 10.00 'da müttefik donanmasına ait 10 büyük savaş gemisinin Çanakkale Boğazı girişindeki tahkimatları bombalamaya başladığını ve bombardımanın saat 18.30 'da sona erdiğini ve gemilerin Bozcaada'ya çekildiğini haber yapmıştır. ${ }^{35}$ Gazete, bombardıman esnasında müttefik donanmasının Agamemnon savaş gemisi ile diğer iki savaş gemisinin Anadolu cihetindeki Türk tahkimatları tarafından vurulduğunu bildirmiştir. ${ }^{36}$ Gazete, 28 Şubat 1915 tarihli sayısında 25 Şubat 1915 bombardımanında Türk tarafindan toplamda beş ölü, on dört yaralı meydana geldiğini, yine aynı haberde 26 Şubat 1915 tarihinde ise müttefik donanmasının bombardımana devam etmesine rağmen Seddülbahir tabyasından yapılan karşı atış neticesinde gemilerin menzil dışına çıktıkları ifade edilmiştir. ${ }^{37}$ Avusturya gazetesi, 25 Şubat 1915 bombardımanı ile ilgili 27 Şubat $1915^{\prime}$ 'de Atina'dan aldığ 1 bir bilgiyi okurları ile paylaşmış olup, bu bilgide 25 Şubat 1915 bombardımanı esnasında müttefik donanmasının tayyarelerini de kullandıklarını ve bir muhrip ve torpidobot filosunun ise savaş gemilerinin bombardımanını perdelediğini belirtmiştir. ${ }^{38}$ Gazete aynı haberinde Çanakkale Boğazı önünde

\footnotetext{
25 "Fortsetzung des Dardanellen Bombardements", Die Neue Zeitung, 1 Mart 1915, s. 1.

${ }^{26}$ Recep Şükrü Apuhan, Çanakkale 1915 Ölüme Koşanlar, Timaş Yayınları, İstanbul 2012, s. 45.

${ }^{27}$ Atabey, age, s. 74.

${ }^{28}$ Atabey, age, s. 74.

${ }^{29}$ Toker ve Toker, age, s. 100.

30 "Die Turkei im Weltkriege: Zur Beschiessung der Dardanellen”, Die Neue Zeitung, 2 Mart 1915, s. 4.

${ }^{31}$ Toker ve Toker, age, s. 100 .

${ }^{32}$ Atabey, age, s. 78 .

${ }^{33}$ Atabey, age, s. 78

${ }^{34}$ Atabey, age, ss. 79-80.

35 "Neue Bombardement der Dardanellen", Die Neue Zeitung, 27 Şubat 1915, s. 3.

36 "Neue Bombardement der Dardanellen", Die Neue Zeitung, 27 Şubat 1915, s. 3.

37 "Die Turkei im Weltkrieg: Neuerisches Bombardement der Dardanellenforts", Die Neue Zeitung, 28 Şubat 1915, s. 4.

38 "Mehrere Feindliche Zerstörer durch die Turkischen Batterien zum Sinken Gebracht", Die Neue Zeitung, 28 Şubat 1915, s. 4.
} 
toplanan müttefik donanmasının sayı olarak Çanakkale Boğazı'nı zorlayabilecek raddeye ulaştı̆̆ını vurgulamıştır. ${ }^{39}$

Avusturya gazetesi, 1 Mart 1915 tarihli İstanbul'dan aldığ bilgiye dayanarak yaptığ 1 haberinde Canakkale Boğazı'ndaki Seddülbahir tabyasına yapılan müttefik unsurlarının çıkarma girişiminin püskürtüldüğünü belirtmiştir. ${ }^{40}$ Aynı haberde beş adet müttefik savaş gemisinin Türk tabyalarına yoğun topçu ateşi açmalarına rağmen Türk bataryalarının karşı ateş açmaları sonucunda gemilerin bölgeden uzaklaştıkları haber yapılmıştır. ${ }^{41}$ Die Neue Zeitung Gazetesi 4 Mart 1915 tarihli yazısında müttefik donanmasının 2 Mart 1915'de Çanakkale Boğazı'nı üç saat boyunca bombaladığını fakat Türk bataryalarının etkili atışlarından ötürü geri çekildiklerini, dört Fransız savaş gemisi ve bir torpidobottan oluşan filonun ise Saroz Körfezi'ni bombalasa da etkili olamadığını ve bu bombardımanda Türk tayyarelerinin de etkili bir şekilde kullanıldığını ifade etmiştir. ${ }^{42}$

Die Neue Zeitung Gazetesi'nin 5 Mart 1915 tarihli haberinde müttefiklerin Çanakkale Boğazı'ndaki savaşı Balkanlardaki belirsizliği netleştirmek için de kullandıkları yorumu yapılmıştır. Gazeteye göre bu sayede özellikle Yunanistan ve Bulgaristan'1 kendi saflarına çekeceklerine inandıkları ifade edilmiştir. ${ }^{43}$ Gazete aynı haberinde Enver Paşa'dan da bahsetmiş olup Enver Paşa'nın müttefik donanmasının Çanakkale Boğazı'na muhtemel bir müttefik çıkarmasını püskürtmek için her türlü tedbiri aldığını ifade etmiştir. ${ }^{44}$ Gazete, 5 Mart 1915'de Atina'dan aldığ Çanakkale Boğazı'na çıkarma yapmak üzere 60.000 askerinin bulunduğunu ve Türklerin ise bölgeyi savunmak üzere ellerinde 130.000 askeri gücünün bulunduğunu belirtmiştir. ${ }^{45}$ Gazete, aynı günkü başka bir haberinde Atina'da yayın yapan İtalia isimli bir gazeteden alıntı yaparak Çanakkale Boğazı önündeki müttefik donanmasının (zırhlı, kruvazör, muhrip torpidobot, denizaltı, mayın gemisi vs.) 70 gemiden oluştuğunu haber yapmıştır. ${ }^{46}$ Gazete, Çanakkale Boğazı önünde müttefiklerin bu üstün donanma gücüne rağmen bölgeye bir kara çıkarması olmaksızın Çanakkale Boğazı'nda bir başarı elde etmelerinin mümkün olmayacağ değerlendirmesinde bulunmuştur. ${ }^{47}$ Avusturya gazetesi, 6 Mart 1915 tarihinde Yunanistan'da yayın yapan Agence d'Athenes isimli bir ajansin 27 Şubat 1915 tarihinde müttefik donanmasının Çanakkale Boğazı'na çıkarma gerçekleştirdiği şeklindeki haberini 4 Mart 1915'de İstanbul'da yayın yapan Agence Telegraphique Milli isimli bir Türk ajansının yalanladığını belirtmiştir. Bunula birlikte Die Neue Zeitung Gazetesi, Aynı ajansın Çanakkale Boğazı'ndaki Türk tahkimatlarının şu ana kadar müttefik donanmasını belirli bir hattın gerisinde tuttuğunu ve bölgeye hiçbir şekilde çıkarma gerçekleştirmedikleri şeklindeki haberine yer vermiştir. ${ }^{48}$

Die Neue Zeitung, 5 Mart 1915 tarihli haberinde müttefik donanmasının bir kısmının 3 Mart 1915'de Çanakkale Boğazı giriş tahkimatlarını bombaladığını, bombardımanı savaş gemileri

\footnotetext{
39 "Mehrere Feindliche Zerstörer durch die Turkischen Batterien zum Sinken Gebracht", Die Neue Zeitung, 28 Şubat 1915, s. 4.

40 "Der Kampf um die Dardanellen”, Die Neue Zeitung, 3 Mart 1915, s. 4.

41 "Der Kampf um die Dardanellen”, Die Neue Zeitung, 3 Mart 1915, s. 4.

42 "Der Kampf um die Dardanellen", Die Neue Zeitung, 4 Mart 1915, s. 3.

43 "Der Beschiessung der Dardanellen Bleib Bisher ohne Jeden Erfolg", Die Neue Zeitung, 5 Mart 1915, s. 1.

44 "Der Beschiessung der Dardanellen Bleib Bisher ohne Jeden Erfolg", Die Neue Zeitung, 5 Mart 1915, s.1.

45 "Landung von Englisch-Französishen Truppen", Die Neue Zeitung, 5 Mart 1915, s. 3.

46 “Die Turkei war Vorbereiter", Die Neue Zeitung, 5 Mart 1915, s. 3.

47 "Ein Englischer Marinesachmann über die Operationen gegen die Dardanellen", Die Neue Zeitung, 5 Mart 1915 , s. 3.

48 "Keine Landungs Feindlicher Truppen auf der Dardanellen Halpinsel: Eine Griechische Lügenmeldungs", Die Neue Zeitung, 6 Mart 1915, s. 5.
} 
$\overline{\text { yaparken bu gemileri çevreleyen on adet torpidobotun da onları koruduğunu belirtmiştir. }{ }^{49}}$ Gazete aynı haberinde dört adet Fransız savaş gemisi ve çok sayıda gambotun ise Bolayır'ı bombaladığını belirtmiş olup müttefik donanmasının bu bombardımanının da daha önceki bombardımanlar gibi alışılmış bir menzilden gerçekleştiğini ve Türk tahkimatlarında bir hasar meydana getirmediğini vurgulamıştır. ${ }^{50}$ Gazete, 4 Mart 1915 'de müttefik donanmasının yine Çanakkale Boğazı giriş tahkimatlarını etkisiz bir şekilde bombaladıklarını belirtmiştir. ${ }^{51}$

Gazete, Çanakkale Boğazı'ndaki müttefik donanmasının faaliyetlerini anlatırken Yunanistan'a ait Limni Adası'nın müttefik donanması tarafından üs olarak kullanıldığını belirtmiştir. ${ }^{52} 7$ Mart 1915 tarihinde öğleden sonra altı büyük savaş gemisinin Çanakkale Boğazı'ndaki Türk tahkimatlarını bombaladığını haber yapan Avusturya gazetesi, Türk tahkimatlarının başarılı bir şekilde karşılık verdiğini vurgulamıştır. ${ }^{53}$ Gazete aynı yazısında Çanakkale Boğazı'ndaki müttefik donanmasına İngiliz donanmasına ait İresistible ve Majestic savaş gemilerinin de katıldığını ve Hamburger Nachrichten gazetesinin 8 Mart 1915 tarihli sayısına atıf yaparak Çanakkale Boğazı önünde halihazırda 38 İngiliz ve 21 Fransız savaş gemisinin (zırhlı, kruvazör, muhrip, torpidobot, denizaltı, mayın tarama gemisi vs.) bulunduğunu ifade etmiştir. ${ }^{54}$ Gazete, 11 Mart 1915 tarihli yazısında Fransa'dan aldığ bir haberi okurları ile paylaşmış olup Fransız Petit Marseillasis gazetesinin 10 Mart 1915 tarihinde -18 Mart 1915 taarruzunu kastederek- önümüzdeki birkaç gün içerisinde müttefik donanmasının Çanakkale Boğazı'na saldırı gerçekleşeceği haberini yaptığını bildirmiştir. ${ }^{55}$

Volume 12

Issue 4

August

2020 Gazete, 12 Mart 1915 tarihinde Çanakkale Müstahkem Mevki Komutanlığı'nın bölgeyi savunmak için Çanakkale Boğazı'na muazzam sayıda mayın döktüğünü belirtip ${ }^{56}$ gerek karada gerek denizde Çanakkale Boğazı'nın savunulması hususunda üst düzey tedbirlerin alındığını ve savunmak amaçlı olan bu tedbirlerin ancak müttefik donanmasının Çanakkale Boğazı'na girmeye cesaret etmesi ile ortaya çıkacağı tespitinde bulunmuştur. ${ }^{57}$ Gazete, 12 Mart 1915 tarihinde Fransız donanmasının Çanakkale Boğazı giriş tahkimatlarını bombaladığını, fakat havanın sisli olması dolayısıyla bombardımanın etkisiz olduğunu belirtmiştir. ${ }^{58}$

\section{18 Mart 1915 Deniz Muharebesi}

Müttefik donanma komutanı Amiral de Robeck, tüm deniz gücü ile boğazı zorlayarak İstanbul'a ulaşmaya karar verdi. ${ }^{59}$ Amaç, boğazın her iki yakasındaki bataryaların susturulması ve mayınların ayıklanması suretiyle açılacak olan yoldan filoyu geçirmekti. ${ }^{60} \mathrm{Bu}$ hedef doğrultusunda donanma A,B ve C olmak üzere üç saldırı hattına bölündü. ${ }^{61}$ Amiral de Robeck, komutasındaki hücum planına göre; birinci tümende, Queen Elizabeth, Inflexible, Agamennon ve Lord Nelson gemileri vardı ve saldırıyı başlatacak olan gemiler de bunlard $1 .{ }^{62} \mathrm{Bu}$ üç gemiyi

\footnotetext{
49 “Die Beschiessung der Dardanellen”, Die Neue Zeitung, 5 Mart 1915, s. 3. (Gazetenin 3 Mart 1915'de İstanbul Ana Karargâhtan aldığı bilgiye dayanarak yaptığı haber.)

50 “Die Beschiessung der Dardanellen”, Die Neue Zeitung, 5 Mart 1915, s. 3. (Gazetenin 3 Mart 1915'de İstanbul Ana Karargahtan aldığı bilgiye dayanarak yaptığı haber.)

51 "Wiederholles Erfolgtes Bombardement der Dardanellenforts", Die Neue Zeitung, 5 Mart 1915 s. 5.

52 "Die Griechische Insel Lemnos als Englisch-Französische Flottenbasis", Die Neue Zeitung, 7 Mart 1915, s. 3.

53 "Der Kampf um die Dardanellen", Die Neue Zeitung, 9 Mart 1915, s. 4.

54 "Der Kampf um die Dardanellen”, Die Neue Zeitung, 9 Mart 1915, s. 4

55 "Unterbrechung der Aktion gegen die Dardanellen", Die Neue Zeitung, 11 Mart 1915, s. 2.

56 "Die Verteidigung der Dardanellen", Die Neue Zeitung, 12 Mart 1915, s. 4.

57 "Eine Fahrt in die Dardanellen", Die Neue Zeitung, 12 Mart 1915, s. 4.

58 "Neuerliche Erfolglose Beschiessung der Dardanellen", Die Neue Zeitung, 13 Mart 1915, s. 3.

${ }^{59}$ Atabey, age, ss. 111-112.

${ }^{60}$ Karal, age, ss. 438-439.

${ }^{61}$ Nigel Steel-Peter Hart, Gelibolu Yenilgisinin Destanı, (çev: Mehmet Harmacı), Epilson Yayıncılık, İstanbul 2005, s. 30.

${ }^{62}$ Alan Moorehead; Gelibolu, (çev: Ali Cevat Akkoyunlu), Doğan Yayıncılık, İstanbul 2005, s. 53.
} 
kuzey kanatta Prince George ve güney kanatta ise Triumph savaş gemileri koruyacaktı. ${ }^{63}$ İkinci tümeni ise Fransız Amiral Guepratte komutasında Suffren, Bouvet, Gaulois ve Charlemagne adlı Fransız savaş gemileri oluşturuyordu. ${ }^{64}$ Üçüncü tümen ise Ocean, İrresistible, Albion, Vengeance, Swiftsure ve Majestic savaş gemilerinden oluşturulmuş ve sırası geldiğinde ikinci tümenin yerini almak üzere yedekte bekletilmiştir. Son olarak ise Dublin, Cornwallis, Canapus, Dorthmouth kruvazörleri gelmekte olup Cornwallis ve Canopus mayın tarayacak diğer iki savaş gemisi ise sahra bataryalarını vurmaya çalışacaktı. ${ }^{65}$

18 Mart 1915 sabahı, saat 10.30'dan itibaren müttefik donanması 16 büyük harp gemisi ile kalenin istihkâmlarını ve bataryalarını susturmak için iki saf halinde boğaza girdi. ${ }^{66}$ Avusturya gazetesi ise müttefik donanmasının Çanakkale Boğazı'na giriş saatini 11.30 olarak vermiş olup savaş gemisi sayısını ise 14 olarak belirtmiştir. ${ }^{67}$ Gazete, Türk tahkimatlarının karşı ateşi sonucunda müttefik donanmasının bir kısmının saat 15.00 'de geri çekildiğini geri kalan kısmının ise aralıklarla ateşe devam ederek onların da saat 17.00 'de tamamen geri çekildiğini belirtmiştir. Aynı haberde bu harekât neticesinde İngiliz donanmasına ait Irresistible ve Fransız donanmasına ait Bouvet savaş gemilerinin battığ gemisinin ise ağır hasara uğratılarak ${ }^{68}$ savaş gemisinin Bozcaada' ya çekildiğini bildirmiştir. ${ }^{69}$ Gazete aynı güne ait bir başka bir haberinde ise 18 Mart 1915 savaşında İngiliz donanmasına ait biri Irresistible olmak üzere iki adet İngiliz savaş gemisinin battığı haberini vermiştir. ${ }^{70}$

Avusturya gazetesi, müttefik donanmasının seyri esnasında onların ilerleyişine yardımcı olmak amacıyla çok sayıda muhrip ve torpidobotların da önden ilerlediklerini ifade etmiştir. ${ }^{71}$ $\mathrm{Bu}$ gemilerden Triumph, saat 11.15 'de Anadolu yakasındaki Haleli sirtlarına ilk mermileri atmış olup diğer gemiler ise saat 11.40 itibariyle $15.000 \mathrm{~m}$ mesafeden ağır topları ile iç tabyalara isabetli şekilde ateş etmeye başladılar. Ağır bombardıman sebebi ile Türk bataryaları ilk etapta karşıl1k veremediler. ${ }^{72}$ Saat 12.30 'da Amiral de Robeck, Fransız savaş gemilerinin oluşturduğu İkinci Tümen'e kıyılara yaklaşıp yakın mesafeden bombardımanı sürdürme talimatı verdi. Bu gemiler kıyıya 400 m yaklaşıp Rumeli'de Kilitbahir ile Mesudiye tabyasını ve Anadolu yakasında ise Dardanos ve Beyaztepe mevkilerine ateş etmeye devam ettiler. ${ }^{73}$ Saat 12.30 'da Gaulois zırhlısı mürettebatını Dublis kruvazörüne naklederek savaştan çekildi. ${ }^{74}$ Fransız savaş gemisi Bouvet ise 18 Mart 1915'de Nusret Mayın Gemisi'nin dökmüş olduğunu mayına çarparak battı ve 639 kişilik mürettebattan sadece 40 kişi kurtulabildi. ${ }^{75}$

Avusturya gazetesi, Bouvet zırhlısının batışını Atina'dan 25 Mart 1915 tarihli elde ettiği bir bilgiye dayanarak haber yapmış olup bu haberini de Bouvet zırhlısından sağ kurtulan bir denizciden elde etmiştir. ${ }^{76}$ Sağ kurtulan denizcinin ifadesine göre, Bouvet zırhlısı, 18 Mart

\footnotetext{
${ }^{63}$ Karal, age, s. 439; Atabey, age, s. 112.

${ }^{64}$ A. Thomazi, Çanakkale Deniz Savaşı, (çev: Hüseyin Işık), Genelkurmay Basımevi, Ankara 1997, s. 37.

${ }^{65}$ Karal, age, s. 439.

${ }^{66}$ Liman von Sanders, Türkiye'de Beş Yıl, (çev: Eşref Bengi Özbilen), Türkiye İş Bankası Yayınları, İstanbul 2014, s. 82.

67 “Der Kampf um die Dardanellen”, Die Neue Zietung, 20 Mart 1915, s.3.

68 "Der Kampf um die Dardanellen”, Die Neue Zietung, 20 Mart 1915, s. 3.

69 "Ein Beschadigtes Englisches Panzerschiff Nach Tenedos Geschleppt", Die Neue Zeitung, 20 Mart 1915, s. 4.

70 "Zwei Englische Panzerschiffe vor den Dardanellen zum Sinken Gebracht", Die Neue Zeitung, 20 Mart 1914, S. 4

71 “Das Vorgestrige Bombardement”, Die Neue Zeitung, 20 Mart 1915, s.4.

${ }^{72}$ Atabey, age, ss. 111-112.

${ }^{73}$ Karal, age, s. 441.

${ }^{74}$ Atabey, age, ss. 116-117.

${ }^{75}$ Atabey, age, s. 119.

76 “Vom Panzerkreuzer Bouvet: Mitteilungen Eines Geretten Matrosen”, Die Neue Zeitung, 26 Mart 1915, s.3.
} 
1915 günü Hamidiye tabyasına ateş açmaya çalışmasına rağmen yüksek dalgalardan ötürü başarı elde edememiştir. ${ }^{77}$ Denizci, bombardıman esnasında toplarının bir kısmının aşırı derecede zarar gördüğünü ifade etmiştir. ${ }^{78}$ Kendisi, gemi komutanının geminin tüm toplarını Türk tahkimatlarına nişan alma emri verdiği esnada geminin mayına çarptığını ve gemide korkunç bir hava basıncı meydana geldiği için geminin kısa süre içerisinde battı̆̆ını belirtmiştir. ${ }^{79}$ Gazete, 20 Mart 1915 tarihli Bouvet savaş gemisinin batırılışı ile ilgili haberinde 18 Mart 1915 'de Türk bataryalarının bu savaş gemisine çok sayıda isabet kaydettiklerini ve bu yüzden gemideki tüm topların susturulduğunu ifade etmiştir. Haberin devamında Türk bataryalarının etkili isabetlerinden ötürü gemide yangın meydana geldiği ve gemi personelinin çabalarına rağmen yangının geminin iç kesimlerine sirayet ettiği ve daha sonra da gemide büyük bir patlama meydana gelip geminin sulara gömüldüğü belirtilmiştir. Bununla birlikte, Fransız savaş gemisi Bouvet'in Çanakkale Boğazı'nda batırılışının Almanya'da büyük bir sevinç meydana getirdiği vurgulanmıştır. ${ }^{80}$

Saat 16.10 'da Bouvet savaş gemisinin yanında manevra yapmaya çalışan Inflexible savaş gemisi bir mayına çarptığını bildirerek yan yatmaya başladı ve gemi büyük bir hasar alarak ger çekilmek zorunda kald1. ${ }^{81}$ Ocean zırhlısı, Irresistible'ın yanında kalarak onu yedeklemeye çalıştı, ancak akıntının her iki gemiyi de Anadolu kıyılarına doğru sürüklemesi nedeni ile başarılı olamayıp saat 18.00 'de Irresistible'1 terk etti. Ancak Ocean zırhlıs1 da Bouvet zırhlısının battığı yerde mayına çarptı ve personel ve komutan da gemiyi terk etmek zorunda kaldılar. $^{82}$ Saat 18.00 'de müttefik donanmasına ait üç savaş gemisi de muharebe dışı kalmıştı, Amiral de Robeck, mayın tehlikesini de hesaba katarak bu koşullar altında başarıya ulaşamayacağını anlayıp harekâtı durdurmaya karar verdi. ${ }^{83}$

Die Neue Zeitung Gazetesi, 18 Mart 1915 saldırısı sonrasında Çanakkale Boğazı önünde büyük bir sessizliğin olduğunu ${ }^{84}$ ve bu saldırı esnasında Türk tahkimatlarının envanter ve personel bakımından az zayiat verdiklerini ve Türk tahkimatlarının da yeni bir savaşa hazır durumda olduklarını belirtmiştir. ${ }^{85}$ Gazete, 18 Mart 1915 Çanakkale Deniz Muharebesi ile ilgili müttefik donanmasının yaşadığı kayıp hususunda en kapsamlı bilgiyi İngiliz Amiralliği'nin 19 Mart 1915 tarihindeki bildirisini yayınlayarak vermiştir. Bu bildiride; muharebe esnasında İngiliz donanmasına ait Irresistible ve Ocean savaş gemileri ile Fransız donanmasına ait Bouvet savaş gemilerinin mayına çarparak battıklarını ve İngiliz donanmasının insan kaybının çok fazla olmamasına rağmen Bouvet zırhlısının neredeyse tüm personelinin yaşamını yitirdiği bilgisi verilmiştir. ${ }^{86}$

Gazete, 18 Mart 1915 deniz muharebesi ile ilgili müttefik donanmasının savaş gücü hakkında bir tespitte bulunmuş olup müttefik donanmasının toplam olarak 134 adet topa sahip olduğunu belirtmiştir. ${ }^{87}$ Bu top gücünü 14 tane $30,5 \mathrm{~cm}$ 'lik, 2 tane $27 \mathrm{~cm}$ 'lik, 18 tane $14 \mathrm{~cm}$ 'lik, 16 tane $10 \mathrm{~cm}$ 'lik, 26 tane $7,6 \mathrm{~cm}$ 'lik ve 34 tane $4,7 \mathrm{~cm}$ 'lik toplardan ibaret olarak ifade

\footnotetext{
77 “Vom Panzerkreuzer Bouvet: Mitteilungen Eines Geretten Matrosen”, Die Neue Zeitung, 26 Mart 1915, s.3.

78 "Vom Panzerkreuzer Bouvet: Mitteilungen Eines Geretten Matrosen", Die Neue Zeitung, 26 Mart 1915, s.3.

79 "Vom Panzerkreuzer Bouvet: Mitteilungen Eines Geretten Matrosen”, Die Neue Zeitung, 26 Mart 1915, s. 3.

80 "DerUntegang des Panzerkreuzer Bouvet", Die Neue Zeitung, 20 Mart 1915, s. 4.

${ }^{81}$ Robert Rhodes James; Gelibolu Harekâtı, (çev: Haluk Saltıkgil), Belge Yayınları, İstanbul 1965, s. 91.

${ }^{82}$ Nigel Steel-Peter Hart, age, s. 33.

${ }^{83}$ Atabey, age, s. 122.

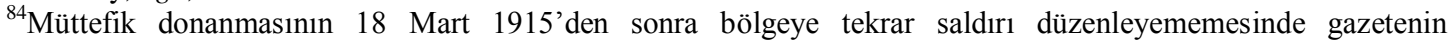
değerlendirmesine göre, kötü hava koşulları da önemli rol oynamıştır. Ayrıntılı bilgi için bkz; "Der Angriff auf die Dardanellen", Die Neue Zeitung, 22 Mart 1915, s.1.

85 "Die Aktion gegen die Dardanellen", Die Neue Zeitung, 21 Mart 1915, s. 3.

86 "Untergang der Drei Feindliche Schlachtschiffe vor den Dardanellen”, Die Neue Zeitung, 21 Mart 1915, s. 3.

87 "Die Verluste der Verbundeten vor den Dardanellen", Die Neue Zeitung, 27 Mart 1915, s. 4.
} 
etmiştir. ${ }^{88} \mathrm{Bu}$ kadar çok sayıda top gücüne ek olarak Quenn Elizabeth savaş gemisinin üstün savaş gücüne de vurgu yapan Avusturya gazetesi, bu savaş gemisinin "canavar" toplarına karş1 Türk tahkimatlarının tüm gün boyunca dayanmayı başardığını belirtmiştir. ${ }^{89} 18$ Mart 1915 deniz muharebesini askeri dünyada silinmez bir iz bırakacak eşsiz bir başarı olarak nitelendiren gazete, bu savaşta müttefiklerin 1200 kayıp vermişken Türklerin ise 20 kayıp verdiklerini ifade etmiştir. $^{90}$

Neue Zeitung Gazetesi, müttefiklerin 18 Mart 1915 yenilgisinin ardından planlarında değişiklik yaptıklarını, Çanakkale Boğazı'na bir kara çıkarması ihtimali üzerine yoğunlaşarak İstanbul'da da bu yönde bir beklenti oluştuğunu okurları ile paylaşmıştır. ${ }^{91}$ Gazete, müttefik donanmasının 18 Mart 1915 yenilgisinin ardından Alman Könischer Zeitung gazetesinden alıntı yaparak müttefiklerin Çanakkale Boğazı'na çıkarma hazırlığı yaptıklarını ve bu yüzden çok sayıda askeri gücü Yunan adalarına yığdıkları bilgisini geçmiştir. ${ }^{92}$ Çanakkale Boğazı'na müttefik çıkarması ihtimali üzerine yoğunlaşmasına rağmen Çanakkale Boğazı'nda ve Gelibolu yarımadasının her iki yakasında toplam 180.000 Türk askerinin bulunduğunu ve Gelibolu'da 40.000, Çanakkale Boğazı'nın Anadolu yakasında ise 30.000 Türk askerinin konuşlu olduğunu belirtmiştir. ${ }^{93}$ Aynı haberde Atina'dan aldığı bilgiye dayanarak müttefiklerin Gelibolu yarımadasına yapacakları saldırıda çıkarma noktasının Saroz Körfezi olacağı da belirtilmiştir. ${ }^{94}$ Neue Zeitung Gazetesi, 24 Mart 1915 tarihli sayısında Times Gazetesi'nden alıntı yaparak İngilizlerin 18 Mart 1915 harekâtı ile ilgili büyük kayılar verdiklerini fakat daha fazla acı çekmemek için kendilerini daha iyi hazırlamaya odaklandıklarını ifade etmektedir. Gazete aynı haberinde İngilizlerin ödedikleri bedelin çok yüksek olduğunun bilincinde olduklarını fakat hiçbir başarının da kolay elde edilmediğini de belirttiklerini ifade etmiştir. ${ }^{95}$

\section{Sonuç}

İngiliz ve Fransızlar Çanakkale Boğazı'nın deniz yoluyla aşıp Osmanlı Devleti'ni savaş dışına ittikten sonra Karadeniz'e açılarak Rusya ile doğrudan bir irtibat sağlamayı planlamakta idiler. Böylece Bulgaristan ve Romanya'yı da kendi saflarına çekeceğini düşünen İngiliz ve Fransızlar, sonuç olarak Almanya'yı güneyden kuşatarak savaşın erken bir tarihte bitmesini sağlamış olacaklardı. Fakat Çanakkale Boğazı, Osmanlı Devleti'nin en müstahkem mevkilerinden birisi olmuş olup Alman kıyı savunma uzmanlarının da yardımları ile de modernize edilişti. Ayrıca ilave mayın hatları ile geçilmesi imkânsız bir yer halini alan Çanakkale Boğazı, modern bir deniz savaşı için hazır duruma getirilmişti.

3 Kasım 1914 tarihinde boğaz giriş istihkâmlarının bombalanması ile başlayan süreç 19 Şubat ve 25 Şubat 1915 saldırıları ile devam etmiştir. Boğazın mayın hatlarını açıp Marmara Denizi'ne girmeyi amaçlayan 18 Mart 1915 saldırısı, Türk donanmasının kıyıya paralel yerleştirdiği mayınlar neticesinde sonuçsuz kalmış ve İtilaf devletleri üç savaş gemisini kaybederek geri çekilmişlerdir. Çanakkale Deniz Savaşları, sonuçları itibariyle İngiliz ve Fransızlara ağır bir darbe indirmiş olup İngiliz ve Fransızların planlarında kapsamlı değişiklikler meydana getirmiştir. Savaşın uzamasına sebep olduğu gibi Türk milletinde büyük bir sevinç yaratarak moral kaynağı olan 18 Mart 1915 deniz savaşı aynı zamanda Osmanlı

\footnotetext{
88 “Die Verluste der Verbundeten vor den Dardanellen", Die Neue Zeitung, 27 Mart 1915, s. 4.

89 "Die Verluste der Verbundeten vor den Dardanellen", Die Neue Zeitung, 27 Mart 1915, s. 4.

90 "Der Untergang des Panzerkreuzer Bouvet", Die Neue Zeitung, 20 Mart 1915, s. 4.

91 "Die Stimmung in Konstantinopel", Die Neue Zeitung, 20 Mart 1915, s. 4.

92 "Truppenlandungen auf Gallipoli? Ein Allgemeiner Angriff Bevorstehend", Die Neue Zeitung, 27 Mart 1915, s.4.

93 “180.000 Mann Turkischen Truppen zur Verteidigung der Dardanellen”, Die Neue Zeitung, 21 Mart 1915, s. 3.

94 "Der Untergang des Panzerkreuzer Bouvet", Die Neue Zeitung, 20 Mart 1915, s.4.

95 "Die Aktion gegen die Dardanellen: Eine Englische Stimme”, Die Neue Zeitung, 24 Mart 1915, s.3.
} 
Devleti'nin Almanya ve Avusturya-Macaristan İmparatorluğu ile olan müttefikliği de pekişmiştir.

18 Mart Deniz Savaşı süresince Avusturya-Macaristan'da yayınlanan Die Neue Zeitung gazetesinin Ağustos 1914-Nisan 1915 arası yaptığ 1 haberlerde Osmanlı Devleti’nin müttefiki olması sebebi ile çatışmaları günü gününe takip ettiği ve Osmanlı Devleti'nin başarılarını destekler nitelikte haberler yaptığı göze çarpmaktadır.

\section{Kaynakça}

\section{Gazeteler}

Die Neue Zeitung

"Die Dardanellensperre: Vorkehrung der Turkei für Einen Konfliktfall”, Die Neue Zeitung, 3 Ekim 1914, Nr. 272

“Die Sperrung der Dardanellen”, Die Neue Zeitung, , 6 Ekim 1914, Nr. 275

“Der Kampf um die Dardanellen”, Die Neue Zeitung, 5 Mart 1915, Nr. 64

“Bombardement der Dardanellen”, Die Neue Zeitung, 5 Kasım 1914, Nr. 305

"Beschiessung der Dardanellen Forts”, Die Neue Zeitung, 6 Kasım 1914, Nr. 306

"Eine Neue Aktion der Englishe-Französischen Flotte gegen Dardanellen", Die Neue Zeitung, 25 Aralık 1914, Nr. 355

"Einigung England mit Russland in der Dardanellen Frage", Die Neue Zeitung, 12 Ocak 1915, Nr. 12

"Ein Englisch-Russisches Geheimabkommen über Dardanellen", Die Neue Zeitung, 3 Mart 1915, Nr. 62

“Fortsetzung des Dardanellen Bombardements", Die Neue Zeitung, 1 Mart 1915, Nr. 60

"Die Turkei im Weltkriege: Zur Beschiessung der Dardanellen”, Die Neue Zeitung, 2 Mart 1915, Nr. 61

"Neue Bombardement der Dardanellen”, Die Neue Zeitung, 27 Şubat 1915, Nr. 58

Die Turkei im Weltkrieg: Neuerisches Bombardement der Dardanellenforts", Die Neue Zeitung, 28 Şubat 1915, Nr. 59

"Mehrere Feindliche Zerstörer durch die Turkischen Batterien zum Sinken Gebracht", Die Neue Zeitung, 28 Şubat 1915, Nr. 59

“Der Kampf um die Dardanellen”, Die Neue Zeitung, 3 Mart 1915, Nr. 62

“Der Kampf um die Dardanellen”, Die Neue Zeitung, 4 Mart 1915, Nr. 63

"Der Beschiessung der Dardanellen Bleib Bisher ohne Jeden Erfolg", Die Neue Zeitung, 5 Mart 1915, Nr. 64

"Landung von Englisch-Französishen Truppen”, Die Neue Zeitung, 5 Mart 1915, Nr. 64

“Die Turkei war Vorbereiter”, Die Neue Zeitung, 5 Mart 1915, Nr. 64

"Ein Englischer Marinesachmann über die Operationen gegen die Dardanellen", Die Neue Zeitung, 5 Mart 1915, Nr. 64 
"Keine Landungs Feindlicher Truppen auf der Dardanellen Halpinsel: Eine Griechische Lügenmeldungs", Die Neue Zeitung, 6 Mart 1915, Nr. 65

“Die Beschiessung der Dardanellen”, Die Neue Zeitung, 5 Mart 1915, Nr. 64

"Wiederholles Erfolgtes Bombardement der Dardanellenforts", Die Neue Zeitung, 5 Mart 1915, Nr. 64

"Die Griechische Insel Lemnos als Englisch-Französische Flottenbasis", Die Neue Zeitung, 7 Mart 1915, s. 3, Nr. 66

“Der Kampf um die Dardanellen”, Die Neue Zeitung, 9 Mart 1915, Nr. 68

“Unterbrechung der Aktion gegen die Dardanellen”, Die Neue Zeitung, 11 Mart 1915, Nr. 70

“Die Verteidigung der Dardanellen”, Die Neue Zeitung, 12 Mart 1915, Nr. 71

"Eine Fahrt in die Dardanellen", Die Neue Zeitung, 12 Mart 1915, Nr. 71

"Neuerliche Erfolglose Beschiessung der Dardanellen", Die Neue Zeitung, 13 Mart 1915, Nr. 72

"Der Kampf um die Dardanellen", Die Neue Zietung, 20 Mart 1915, Nr. 79

“Der Kampf um die Dardanellen”, Die Neue Zietung, 20 Mart 1915, Nr. 79

"Ein Beschadigtes Englisches Panzerschiff Nach Tenedos Geschleppt", Die Neue Zeitung, 20 Mart 1915, Nr. 79

"Zwei Englische Panzerschiffe vor den Dardanellen zum Sinken Gebracht", Die Neue Zeitung, 20 Mart 1914, Nr. 79

"Das Vorgestrige Bombardement", Die Neue Zeitung, 20 Mart 1915, s.4, Nr. 79

"Vom Panzerkreuzer Bouvet: Mitteilungen Eines Geretten Matrosen", Die Neue Zeitung, 26 Mart 1915, s.3, Nr. 85

DerUntegang des Panzerkreuzer Bouvet”, Die Neue Zeitung, 20 Mart 1915, Nr. 79

Die Aktion gegen die Dardanellen”, Die Neue Zeitung, 21 Mart 1915, Nr. 80

"Untergang der Drei Feindliche Schlachtschiffe vor den Dardanellen", Die Neue Zeitung, 21 Mart 1915, Nr. 80

“Die Verluste der Verbundeten vor den Dardanellen”, Die Neue Zeitung, 27 Mart 1915, Nr. 86

“Der Untergang des Panzerkreuzer Bouvet”, Die Neue Zeitung, 20 Mart 1915, Nr. 79

“Die Stimmung in Konstantinopel”, Die Neue Zeitung, 20 Mart 1915, Nr. 79

"Truppenlandungen auf Gallipoli? Ein Allgemeiner Angriff Bevorstehend”, Die Neue Zeitung, 27 Mart 1915, Nr. 86

“180.000 Mann Turkischen Truppen zur Verteidigung der Dardanellen”, Die Neue Zeitung, 21 Mart 1915, Nr. 80

Der Untergang des Panzerkreuzer Bouvet”, Die Neue Zeitung, 20 Mart 1915, Nr. 79

"Die Aktion gegen die Dardanellen: Eine Englische Stimme", Die Neue Zeitung, 24 Mart 1915, Nr. 83 


\section{Tetkik Eserler}

APUHAN, Recep Şükrü; Çanakkale 1915 Ölüme Koşanlar, Timaş Yayınları, İstanbul 2012.

ATABEY, Figen; Çanakkale Muharebesinde Deniz Cephesi, Türk Tarih Kurumu Yayınları, Ankara 2014.

AYDEMIR Şevket Süreyya, Makedonya'dan Orta Asya'ya Enver Paşa, C.II, Remzi Kitabevi, İstanbul 1981.

BURAK, Durdu Mehmet; Birinci Dünya Savaşı’nda Türk-İngiliz İlişkileri, Babil Yayıncılık, Ankara 2004.

GÜLBOY, Burak, Birinci Dünya Savaşı Tarihi, Altın Kitaplar Yayınevi, İstanbul 2004.

JAMES, Robert Rhodes; Gelibolu Harekâtı, (çev: Haluk Saltıkgil), Belge Yayınları, İstanbul 1965.

KARAL, Enver Ziya; Osmanlı Tarihi, C.IX, TTK Basımevi, Ankara 1996.

MCMEEKİN, Sean; I. Dünya Savaşı'nda Rusya'nın Rolü, (çev: Nurettin Elhüseyni), Yapı Kredi Yayınları, İstanbul Şubat 2013.

MOOREHEAD, Alan; Gelibolu, (çev: Ali Cevat Akkoyunlu), Doğan Kitapçılık, İstanbul 2005.

ÖZDEMIR Bülent, MUTAF Abdülmecit, Çanakkale Muhârebatı, Türk Tarih Kurumu Yayınları, Ankara 2012.

SANDERS, Liman Von; Türkiye'de Beş Yll, (çev: Eşref Bengi Özbilen), Türkiye İş Bankası Yayınları, İstanbul 2014.

STEEL, Nigel- HART, Peter; Gelibolu Yenilginin Destanı, (çev: Mehmet Harmanc1), İstanbul: Epsilon Yayıncilık, Mart 2005.

THOMAZİ A.; Çanakkale Deniz Savaşı, (çev: Hüseyin Işık), Genel Kurmay Basımevi, Ankara 1997.

TOKER Hülya-TOKER Mustafa; Çanakkale Muharebeleri Kronolojisi, Alfa Yayınevi, İstanbul Mart 2015.

\section{Makaleler}

GÖK, Bilal; "Çanakkale Deniz ve Kara Savaşları: Sebepleri, Gelişimi ve Sonuçları”, Kafkas Üniversitesi Illahiyat Fakültesi Dergisi, 2, 2014, ss.117-145.

TUNA, Ozan; “Amiral Souchon'un Donanma Komutanı Olması ve Rus Limanlarının Bombalanması (29 Ekim 1914)", Ankara Üniversitesi Osmanlı Tarihi Araştırma ve Uygulama Merkezi Dergisi (OTAM), Say1: 36, Güz 2014, ss. 201-227. 
Ekler

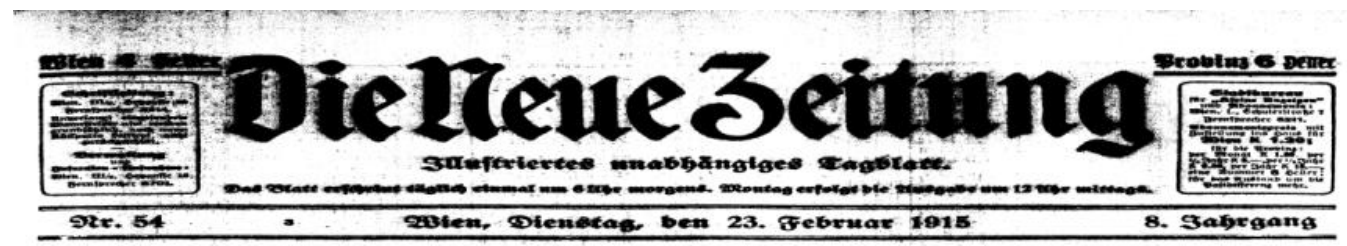

Die zebnte rufifobe Vrme vörig vernichter.

Ceif Cube उanuex waxben mabeju 141.000 2tulfen gefangen.

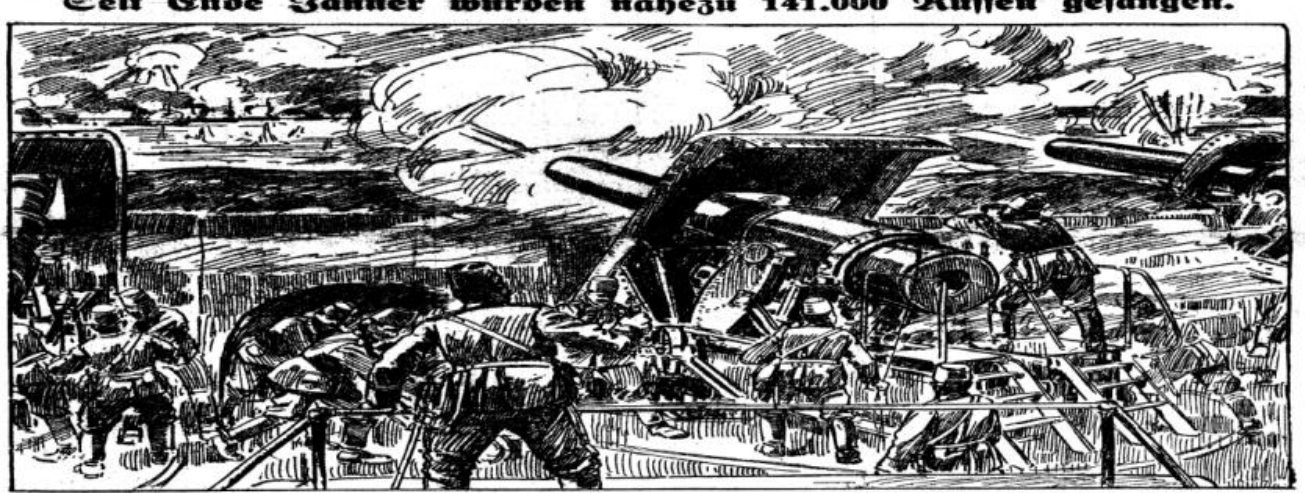

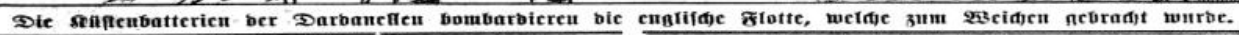

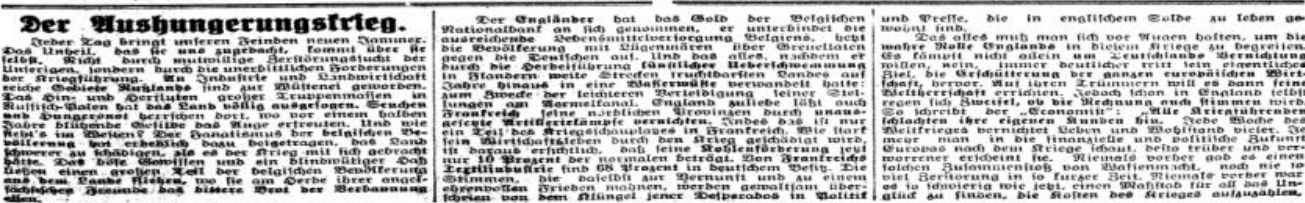

Ek: 1- Çanakkale Boğazı kıyı bataryası İngiliz filosu, 23 Şubat 1915, Nr. 54 
Ozan Tuna - Nazlı Murzioğlu

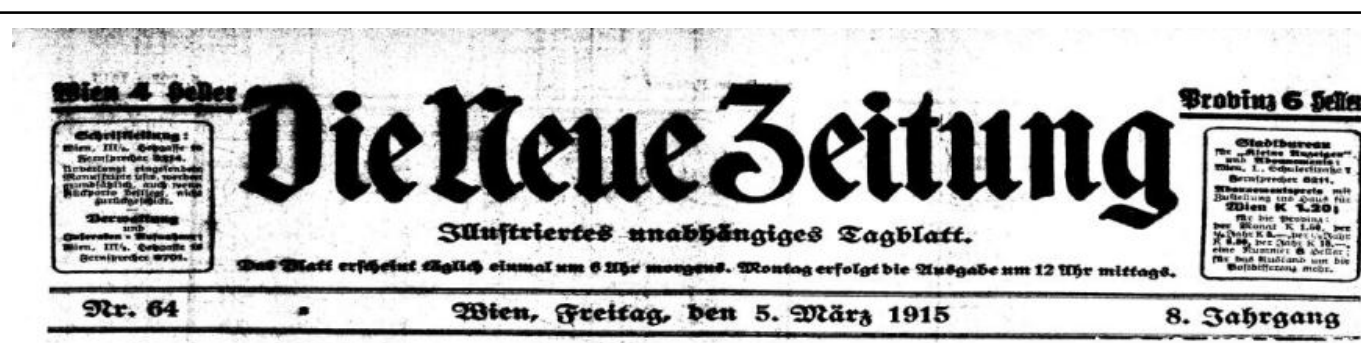

\section{Oute Fortidritte an Der galiaijden, po!nifonen und framāofithen Front.}

Die zeldiebung ber Darbanellen blieb bisher obne ieben Grjolg.

Volume 12

Issue 4

August

2020

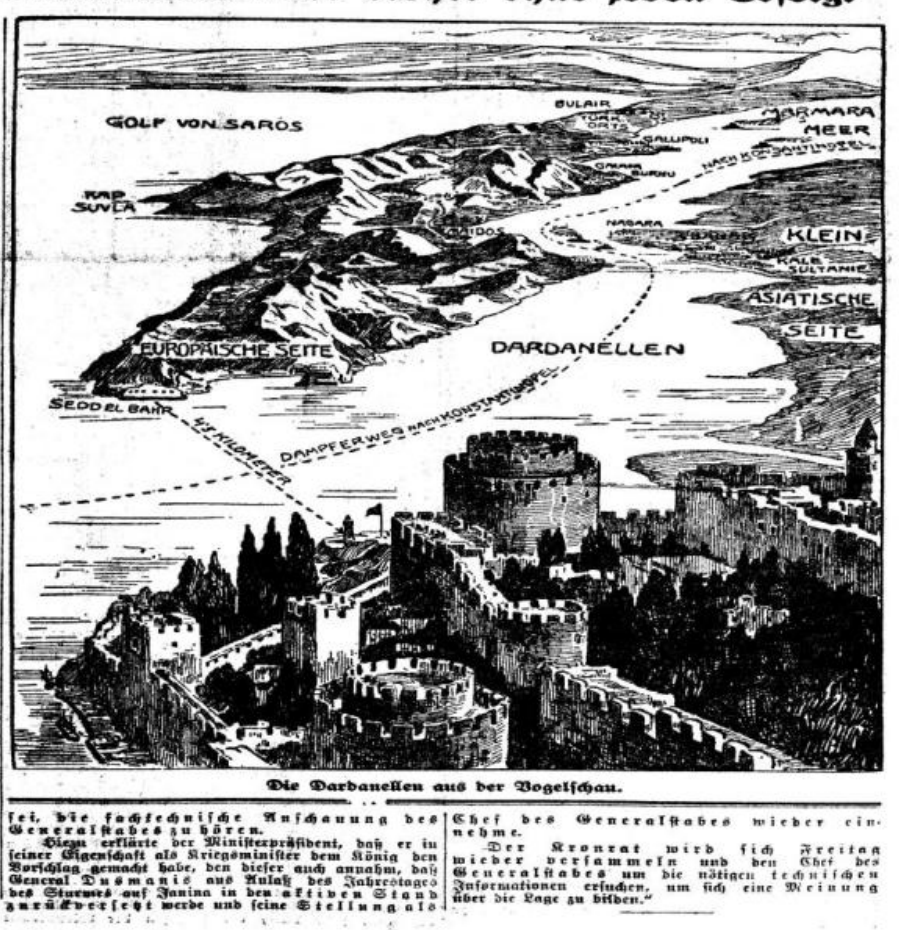

Ek 2: Çanakkale Boğazı'nın Kuşbakışı Görünümü, 5 Mart 1915, Nr. 64 


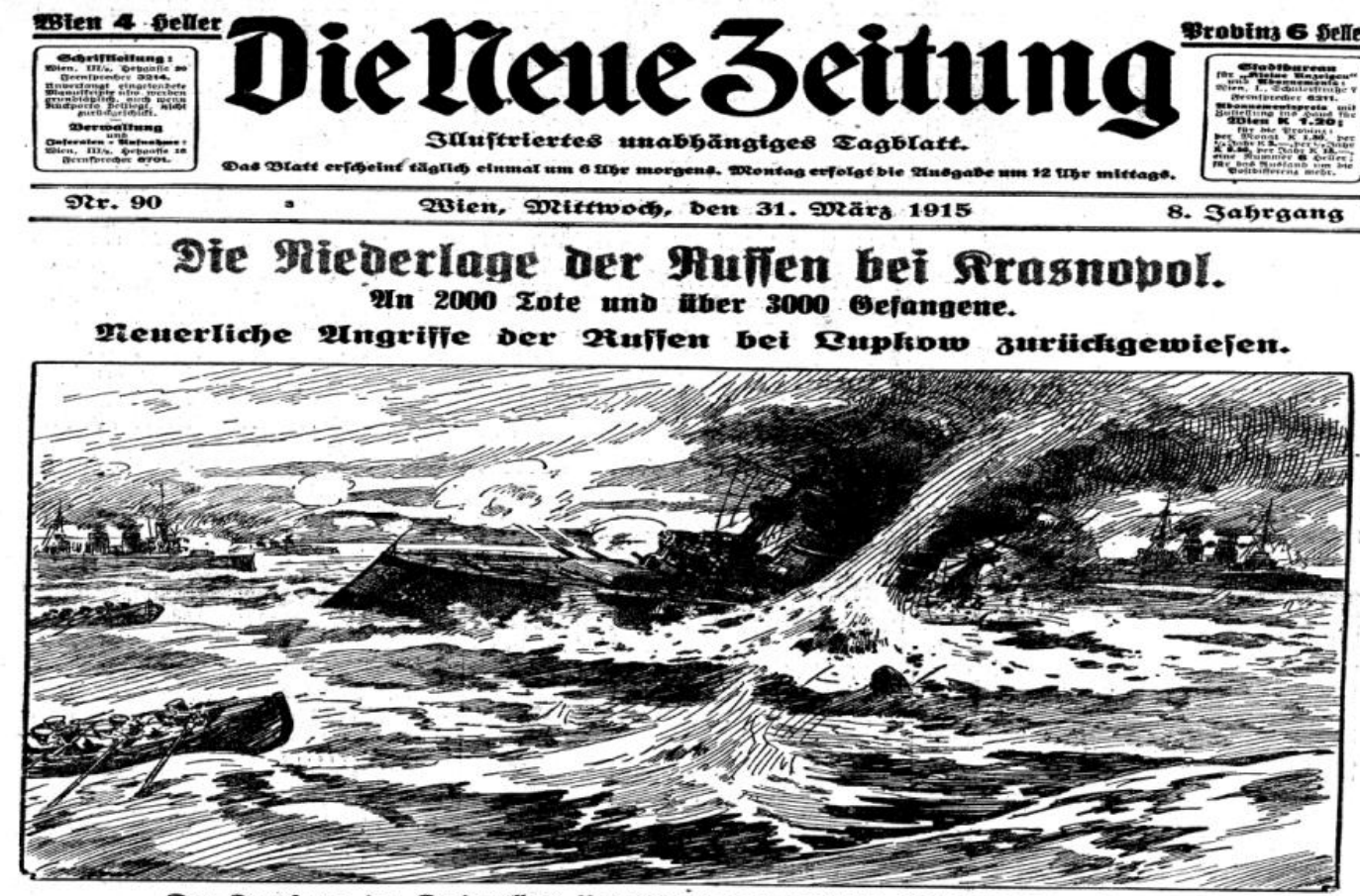

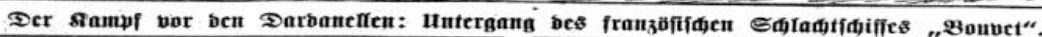

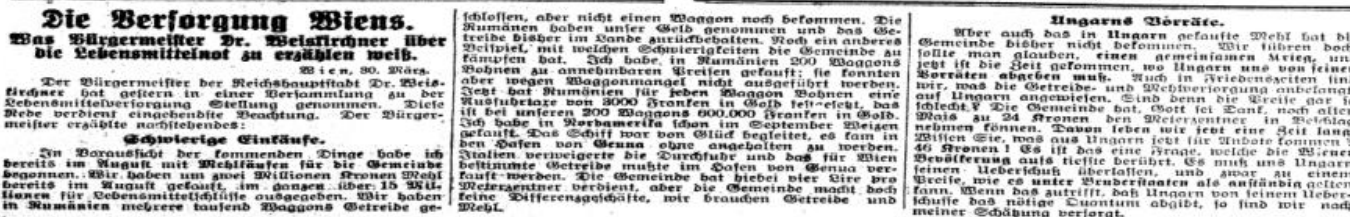

Ek 3: Fransız Savaş Gemisi Bouvet'in Batışı, 31 Mart 1915, Nr. 90 